\title{
ARISTÓTELES E O DEBATE EDUCACIONAL: UMA ANÁLISE A PARTIR DA PEDAGOGIA HISTÓRICO-CRÍTICA
}

\author{
Rafael Rossi ${ }^{1}$, Aline Santana Rossi ${ }^{2}$ \\ ${ }^{1}$ Doutor e pós-doutor em Educação pela Universidade Estadual Paulista - UNESP, Presidente Prudente. Docente e \\ orientador na Faculdade de Educação e no Programa de Pós-Graduação em Educação - PPGEDU - da Universidade \\ Federal do Mato Grosso do Sul - UFMS. ORCID iD: https://orcid.org/0000-0001-8544-3756. E-mail: \\ rafaelrossied@gmail.com \\ ${ }^{2}$ Mestre em Ensino de Ciências, pelo Programa de Pós-Graduação em Ensino de Ciências da Fundação Universidade \\ Federal de Mato Grosso do Sul - UFMS. Participa do Grupo de Estudos Fundamentos da Educação - GEFE, vinculado à \\ Faculdade de Educação da UFMS. ORCID iD: https://orcid.org/0000-0002-8460-317X. E-mail: \\ alinesantanarossi@gmail.com
}

\section{RESUMO}

Este artigo trata de um clássico da reflexão educacional, tanto do ponto de vista da pesquisa, quanto do ponto de vista da prática docente: o filósofo Aristóteles a partir das contribuições da Pedagogia HistóricoCrítica. Não se trata de "aplicar" literalmente as concepções desse pensador de forma apressada e acrítica à escola e à pesquisa em educação contemporânea sem maiores preocupações. Ao contrário, entendemos que o estudo da obra aristotélica, assim como da sociedade grega, pode oferecer subsídios para a compreensão da importância dos clássicos na educação. Este texto trata das bases sociais e históricas da Grécia e dos elementos presentes na obra "Ética a Nicômaco", que ajudam a compreender a particularidade da dimensão educacional e a relevância da cultura humana elaborada para o desenvolvimento das individualidades em formação.

Palavras-chave: Educação. Aristóteles. Clássico.

\section{ARISTOTLE AND THE EDUCATIONAL DEBATE: AN ANALYSIS FROM HISTORICAL-CRITICAL PEDAGOGY}

\begin{abstract}
This article deals with a classic of educational reflection, both from the point of view of research and from the point of view of teaching practice: the philosopher Aristotle from the contributions of Historical-Critical Pedagogy. It is not a matter of literally "applying" the views of this thinker in a hasty and uncritical way to school and research in contemporary education without major concerns. On the contrary, we understand that the study of Aristotelian work, as well as of Greek society, can provide subsidies for understanding the importance of the classics in education. This text deals with the social and historical bases of Greece and the elements present in the work "Ethics to Nicomaches", which help to understand the particularity of the educational dimension and the relevance of human culture developed for the development of individualities in formation.

Keywords: Education. Aristotle. Classic.

\section{ARISTÓTELES Y EL DEBATE EDUCATIVO: UN ANÁLISIS DESDE LA PEDAGOGÍA HISTÓRICO-CRÍTICA RESUMEN}

Este artículo aborda un clásico de la reflexión educativa, tanto desde el punto de vista de la investigación como desde el punto de vista de la práctica docente: el filósofo Aristóteles desde los aportes de la Pedagogía Histórico-Crítica. No se trata de "aplicar" literalmente las opiniones de este pensador de manera apresurada y acrítica a la escuela y la investigación en la educación contemporánea sin mayores preocupaciones. Al contrario, entendemos que el estudio de la obra aristotélica, así como de la sociedad griega, puede aportar subvenciones para comprender la importancia de los clásicos en la educación. Este texto trata sobre las bases sociales e históricas de Grecia y los elementos presentes en la obra "Ética a
\end{abstract}


Nicomaches", que ayudan a comprender la particularidad de la dimensión educativa y la relevancia de la cultura humana desarrollada para el desarrollo de las individualidades en formación.

Palabras clave: Educación. Aristóteles. Clasico.

\section{INTRODUÇÃO}

Este texto parte das reflexões e estudos da pesquisa em andamento intitulada "Educação: Origem, Natureza e Função Social" em que buscamos compreender a particularidade da dimensão educacional a partir dos clássicos da história, da filosofia e da sociologia, analisando seus limites, suas contribuições, lacunas e avanços alcançados. Apresentamos para o debate as contribuições que o estudo da obra do filósofo Aristóteles pode oferecer à pesquisa educacional e, também, à prática docente.

Trata-se de um clássico da filosofia preocupado em desenvolver suas reflexões numa postura de ordem ontológica. Isto significa que Aristóteles não estava preocupado em fundar uma outra metodologia ou uma gnosiologia, mas, antes de tudo, em descobrir a lógica própria do objeto investigado e não lhe imputar uma extrínseca a seu próprio movimento e dinâmica. O filósofo discípulo de Platão se baseava, desse modo, numa prerrogativa que compreende os objetos pesquisados como entes reais e concretos, com uma existência própria e independente da consciência daqueles que os estudam. O cosmos, a Terra, o ser humano e suas relações sociais não são, para Aristóteles, criações autônomas de uma subjetividade que "cria" ou que "recorta" o real. São traduções intelectivas de processos existentes na objetividade e passíveis de serem compreendidos à luz da ciência e da reflexão filosófica.

Apesar de Aristóteles não ter escrito diretamente sobre a educação ("paideia"), seus escritos possuem ricas possibilidades analíticas para a área (ANGIONI, 2017). Uma "paideia completa" nos explica Angioni a partir do estudo da obra aristotélica, "envolve não apenas o aprendizado das disciplinas específicas, que nos torna conhecedores de seus respectivos assuntos, mas também envolve o aprendizado que" inclui a "capacidade de avaliar, de modo certeiro, se explicações em um dado domínio se conformam às regras explanatórias que estão bem justificadas nesse domínio" e a capacidade de "discernir se uma exposição científica segue regras metodológicas adequadas e, enfim, a capacidade de discernir o tipo de argumentação que é apropriado a cada disciplina" (ANGIONI, 2017, p. 193).

Por isso mesmo, acreditamos que em seu livro "Ética a Nicômaco" existem elementos de ordem ontológica indispensáveis para a reflexão educacional. Não estamos afirmando uma relação mecânica e rígida de buscar algo na obra e "aplicá-lo" indistintamente na realidade contemporânea educativa. Ao contrário, a própria postura ontológica do filósofo, em nossa compreensão, é já uma lição importante para a pesquisa educacional na atualidade, por exemplo. Isto é: o fato de Aristóteles intentar mobilizar seus conhecimentos para descobrir e desvendar a realidade em sua processualidade é um indicativo de extrema relevância para os pesquisadores educacionais de hoje, no intuito de colocarem a sua subjetividade para compreender e explicitar a dinâmica real tal como ela é em sua essência. Essa é uma perspectiva baseada na Pedagogia Histórico-Crítica (PHC) em que a educação é analisada em meio ao campo de limites e de possibilidades de cada totalidade social historicamente produzida (SAVIANI; DUARTE, 2012).

O desenvolvimento da cultura, das artes, do direito, da economia e da administração, por exemplo, atingiu níveis realmente admiráveis durante o modo de produção escravista, tendo na Grécia o seu esplendor. A base de tudo isso era a exploração no campo, por isso mesmo, as cidades eram em sua origem "conglomerados urbanos de proprietários de terras" (ANDERSON, 1991, p. 19).

O tipo das mercadorias produzidas nas cidades se baseava, fundamentalmente, em produtos têxteis, cerâmica, mobília e utensílios de vidro. $O$ transporte para tais mercadorias era excessivamente custoso e, com isso, as manufaturas na Antiguidade se desenvolviam pela "descentralização e dispersão, já que a distância ditava mais os custos relativos da produção do que a divisão do trabalho" (ANDERSON, 1991, p. 20).

A Antiguidade era mediterrânea e a maior parte do transporte, em face disto, era 
realizada por água. $O$ transporte marítimo ocupava tamanha importância que, por exemplo, para transportar trigo da Síria para a Espanha (ou seja, de um polo a outro oposto do Mediterrâneo) era mais barato ser feito por embarcações do que enfrentar os 120 quilômetros por terra (ANDERSON, 1991).

É nesse sentido que entendemos ser fundamental a divisão deste texto em mais três momentos. Em primeiro lugar, apresentaremos, de modo extremamente breve, o contexto social e histórico no qual Aristóteles desenvolveu suas elaborações, ou seja, o desenvolvimento, apogeu e declínio grego. Em um segundo momento, explicitamos lições do livro "Ética a Nicômaco" e suas contribuições para a pesquisa e prática em educação, já que:

[...] o estudo crítico dos grandes filósofos, isto é, dos clássicos da filosofia, é uma via de acesso privilegiada à compreensão da problemática humana 0 que tem grande valor educativo, já que a educação não é outra coisa senão o processo através do qual se constitui em cada indivíduo a universalidade própria da espécie humana. (SAVIANI, 1990, p. 07-08)

É importante explicitar o funcionamento e declínio da pólis grega, mesmo que brevemente, pois dessa forma, poderemos entender a relação entre o ideário educacional presente em Aristóteles e suas articulações com o campo de possibilidades ofertado pelo solo social e histórico que viveu. Não se trata de uma relação de mão única ou com qualquer tipo de determinismo. Por outro lado, não entendemos a subjetividade como mera extensão da realidade objetiva, mas sim, como dimensão constitutiva e interventiva também do real. Há uma reciprocidade dialética entre consciência e realidade. As ideias podem interferir e contribuir para transformar ou manter determinados aspectos do real e, ao mesmo tempo, encontram seu escopo de atuação em meio ao campo de possíveis delimitados e construídos histórica e socialmente de modo concreto, efetivo, na prática. Daí nosso intento em "confrontar a história e os processos ideais" e "compreender sua lógica e necessidade", entendendo que o "arcabouço ideal fora matrizado pelos influxos da realidade histórica e que, nesta condição, relevase uma exigência própria em sua natureza de ser assim e não de outro modo" (CHASIN, 2007, p. 31).

Por fim, nossas considerações finais, no intuito de chamar a atenção para a relevância deste clássico perante nossa atualidade e compromisso ético com a educação para além de padrões e prerrogativas egoístas e dogmáticos.

\section{SOCIEDADE GREGA: APOGEU E DECLÍNIO}

A escravidão sempre existiu na Antiguidade, todavia, em outros lugares ela era uma "condição juridicamente impura", englobando outros tipos de servidão. Apenas com as cidades-Estado gregas que a escravidão tomou uma forma absoluta e em expansão. Além dos escravos, existiam camponeses livres, rendeiros e artesãos urbanos em diversas combinações pelas cidades-Estado da Grécia. A escravidão, portanto, era predominante na Grécia dos séculos V e IV a. C. e na Roma do século II a. C. ao século II d. C. (ANDERSON, 1991).

$\mathrm{Na}$ Grécia, foi a primeira vez que os escravos eram utilizados também na manufatura, na agricultura e na indústria. A escravidão e a liberdade helênicas podiam ser compreendidas como indivisíveis, já que uma era uma condição essencial da outra. Esta "profunda mudança jurídica foi em si o correlato social e ideológico do "milagre" econômico forjado pelo advento do modo de produção escravo" (ANDERSON, 1991, p. 23). O estado escravo possibilitava a separação entre a residência e o rendimento, permitindo que o produto excedente que se tornava a base da fortuna das classes dominantes pudesse ser extraído sem a presença delas nas terras. A escravidão na Antiguidade clássica, portanto, incorporava uma brutal degradação do trabalho nos campos, convertendo seres humanos em meios de produção. Na teoria romana, por exemplo, o escravo "da agricultura era designado como sendo um instrumentum vocale, um grau acima do gado, que constituía um instrumentum semi vocale, e dois acima do implemento, que era um instrumentum mutum" (ANDERSON, 1991, p. 24).

A escravidão, dessa forma, era o que unia o campo e a cidade, favorecendo a riqueza das classes dominantes que podia ficar distante das 
terras e, ainda, favorecendo o comércio urbano com seus produtos. Com o modo de produção escravista, existiram vários desenvolvimentos: o aumento das culturas de vinho e azeite, a utilização de moinhos para cereais, a criação das prensas de parafuso, o melhoramento do vidro soprado, o conhecimento sobre plantas e a drenagem dos campos também se desenvolveram (ANDERSON, 1991).

Tudo isso fazia com que a expansão do Estado na Antiguidade se desse por ampliação de terras conquistadas, em outras palavras: aumentava-se o poder conquistando e ampliando o espaço geográfico de uma sociedade. Saque, tributos e escravos, junto com a dominação de maiores porções do espaço, garantiam o crescimento econômico de então. A maior parte do trabalho escravo eram, costumeiramente, prisioneiros de guerra. De modo geral e esquemático, podemos entender três grandes períodos de expansão imperial na Antiguidade: o ateniense, o macedônico e o romano. Para nosso interesse e debate, cujo foco é a educação, iremos nos ater ao ateniense e esboçar o entendimento de Aristóteles.

Com relação à Grécia, podemos dizer que o advento dos tiranos (c. 650-510 a. C.) representou a transição fundamental para a polis clássica. Tratavam-se de autocratas que conseguiram romper com a dominação das antigas aristocracias nas cidades. Os tiranos eram "proprietários de terra mais novos e riqueza mais recente, acumulada durante o crescimento econômico da época precedente, e estendiam seu poder a uma região muito maior graças a concessões à massa sem privilégios dos habitantes das cidades" (ANDERSON, 1991, p. 30). Nesse aspecto, o sistema monetário também foi acompanhado por um crescimento da população e do comércio no mundo grego.

Houve uma pressão das novas fortunas perante as aristocracias que, por fim, terminou por derrubar estas últimas. Assim, os tiranos subiram ao poder no final do século VII e VI a. C. As reformas econômicas dos tiranos, no interesse da população, permitiram o seu poder. Sólon, por exemplo, cerceou a nobreza do monopólio de cargos e dividiu Atenas em quatro classes de renda, sendo as duas primeiras classes reservada às magistraturas mais elevadas, a terceira classe com assuntos administrativos e a quarta com direito a voto na Assembleia dos cidadãos. Nas próximas três décadas que se seguiram, Atenas experimentou um grande crescimento comercial, gerando, também, novos conflitos, com a subida ao poder de Pisístrato. Em seu governo houveram várias construções empregando artífices e trabalhadores urbanos, permitindo um grande tráfego marítimo do Pireu. Além disso, houve a destinação de créditos públicos ao campesinato o que garantiu a sobrevivência de pequenos e médios fazendeiros (ANDERSON, 1991).

Com o surgimento da moeda, do calendário e o aprimoramento e criação de novas técnicas, junto ao surgimento de uma nova classe de comerciantes que passou a rivalizar com a aristocracia agrária, a sociedade grega, pouco a pouco, se torna mais urbana e as elaborações mítico-religiosas passam a ceder e dar espaço para explicações mais racionais, surgindo, enfim, a filosofia (CHAUÍ, 2002). Vejamos todo esse processo com mais calma.

A Grécia clássica possibilitou um ambiente em que os cidadãos pudessem exercitar os seus conhecimentos, suas argumentações, opiniões e cultura. De modo sumário, temos com Sólon o fim da escravidão por dívidas e uma certa ampliação da cidadania, já Clístenes, por sua vez, ampliou o processo anterior e, em face disto, é lembrado por muitos pesquisadores sobre o tema como o ponto fulcral da democracia ateniense que adquire seu auge e decadência com Péricles que permitiu a "mistoforia", isto é, uma remuneração ao cidadão mais carente para que pudesse ter sua participação em assembleias (CHASIN, 2007).

Com a Guerra do Peloponeso, que durou vinte anos, se iniciou a decadência da democracia. Importante apontar que o crescimento econômico em Atenas se baseava na concentração e expansão da propriedade privada fundiária e, igualmente, na existência da mão-deobra escrava (CHASIN, 2007). No século VI a. C. a pólis de Atenas enfrentava um grave problema a respeito da partilha da terra e a grave pobreza de milhares de camponeses. É nesse período que Sólon tenta uma resolução e reformas. Importante, no entanto, observar que "a comunidade política não resistiu, desde o seu nascimento, mais de um século, sem se consumar em crises de grandes proporções" (CHASIN, 2007, p. 14). O conflito das crises camponesas se acentua com Pisístrato e encontra nova tentativa de reforma com Péricles, já que, com este, em decorrência da expansão da cidadania é possível o cidadão desempenhar outra atividade para além do cultivo da terra (CHASIN, 2007). 
Com efeito, bem antes do advento da pólis e, portanto, da cidadania e democracia ateniense, era o oikos que dominava a situação econômica e social. Isto é: trata-se de uma sociedade em que a economia estava estruturada ao redor das necessidades familiares com uma produção limitada e local. Relevante observar que "mesmo quando, a partir de determinado momento, o comércio propriamente dito vem a se instalar, a produção nunca esteve voltada para a troca" (CHASIN, 2007, p. 43). O que se revela no oikos é a relação baseada na unidade familiar, com reduzidos limites para a auto-reprodução.

Os escravos do oikos estavam, por assim dizer, com condições de vida relativamente melhores das quais os tetas viviam, ou seja, aqueles que não pertenciam ao oikos e isto porque estes últimos não usufruíam da proteção dada pelo clã. Além disso, alguns escravos em posição mais favorável poderiam até mesmo participar de alguns assuntos do oikos, fato este que seria impossível na pólis clássica, por isso: "a hierarquia do oikos tem um caráter claramente horizontal e que as diferenças estamentais não constituem um fosso entre as diferentes esferas, como ocorrerá na Atenas do século V" (CHASIN, 2007, p. 51).

No oikos não existe o escravo enquanto mercadoria. Será a Atenas clássica que privatiza o indivíduo, que se faz propriedade móvel, vendida e manipulada a partir das necessidades e conveniências de seu amo" (CHASIN, 2007, p. 51). Já o cativo no oikos, em muitos casos, compartilhava da proteção e estima do seu senhor e o comércio quase não existia, o que dificultava muito a mão-de-obra e, dessa forma, a alternativa mais viável era a pilhagem realizada por meio das guerras (CHASIN, 2007).

O cativo por dívidas, na Grécia arcaica era, portanto, a força de trabalho utilizada de modo mais predominante. Era também, para a aristocracia fundiária, a maneira mais segura de conseguir cativos, pois permitia evitar a guerra e suas consequências. $O$ trabalhador cativo por dívidas, portanto, estava numa posição melhor do que a do escravo, pois ele poderia superar a sua condição, coisa impossível do escravo que era conquistado por guerras ou comprado no mercado poder realizar, a não ser pela vontade do seu senhor (CHASIN, 2007).

Quando Sólon aboliu a escravidão por dívidas, permitiu ao camponês que lhe fosse retirada a condição de trabalhador cativo. Era muito comum, na época da existência dos clãs, uma certa inclinação para a guerra, já que o saque de riquezas era uma maneira encontrada para que o oikos continuasse se reproduzindo. Esta inclinação para a guerra não nasce de valores próprios dos indivíduos, mas, antes disso, de "condições históricas desfavoráveis que impelem os indivíduos a uma incontornável postura aguerrida que, não temendo o confronto, defende até a morte as aquisições e bens que permitam a vida dos clãs, das famílias" (CHASIN, 2007, p. 55).

As relações entre os oikos estavam baseadas, em muitas vezes, no parentesco e o casamento favorecia a articulação e o compromisso entre as famílias, reunindo mais indivíduos para cooperarem na defesa, ataque e pilhagem. Todavia, o chefe de outra família, de outro oikos era encarado de antemão como um inimigo em potencial. A hospitalidade começou a ser encarada e praticada como possiblidade de alianças. Enfim, o oikos era "uma forma comunal fechada, isolada face ao mundo exterior, cuja economia de subsistência lhe impossibilitaria um intercâmbio com outros clãs" (CHASIN, 2007, p. 56).

O comércio nesse período comparece como algo marginal, já que esse arranjo comunal familiar possuía um baixo nível produtivo e a inexistência da moeda, do dinheiro para a realização da mediação no intercâmbio perante os indivíduos. As trocas se realizavam a partir da simples necessidade, evidenciando a tipicidade da produção familiar de economia pastoril com limitado cultivo da terra e sem espaço para a produção de mercadorias pela ausência da produção de excedente. Por isso mesmo, as pilhagens forneciam o meio necessário para adquirir bens e força de trabalho. Interessante notar que, ao contrário do que acontecia na cidade-estado, o oikos não permitia a existência de grandes aquisições de terras, pois isto poderia ir além da sua capacidade de cultivo e produção perante os instrumentos e as condições históricas existentes e, com isso, "a satisfação mínima das necessidades era a essência e marca do oikos" (CHASIN, 2007, p. 59). Isto é: "as forças produtivas assentadas num patamar mínimo de desenvolvimento engendram um homem cuja criação do próprio mundo não pode superar patamares limitados, mundo que, frágil em seu equilíbrio precário, impede o curso de sua reprodução e desenvolvimento" (CHASIN, 2007, p. 59). A decadência do oikos, portanto, que 
impedia o seu desenvolvimento, significou o surgimento das cidades e, depois, da pólis.

Com o século VI tem início o poder político propriamente dito. Com a pólis surge a comunidade dos cidadãos. Os conflitos da terra se acirram e Sólon tenta contornar o problema, resultando na confirmação da pólis. O pequeno camponês continuou na pobreza, todavia, houve o paulatino desaparecimento da escravidão por dívidas e a constituição do escravo-mercadoria. Estamos assistindo, naquele período, à substituição da "propriedade da terra ainda dispersa - utilizada essencialmente sob forma pastoril e no cultivo limitado, típico dos tempos arcaicos -, pela concentração da propriedade privada imóvel e de seu correlato o escravo tornado mercadoria" (CHASIN, 2007, p. 61). O que surge com Sólon, portanto, é a possibilidade de, por meios jurídicos, ter fim "o cativo por dívidas em função de sua substituição por formas de trabalho muito mais impessoais, desprovidas de amarras e de vínculos familiares e, nesse sentido, de proveito muito maior para o proprietário: o escravo comprado nas praças" (CHASIN, 2007, p. 61).

Atenas se destaca pela imposição de seus ataques e, ao mesmo tempo, se enfraquece, com a Guerra do Peloponeso em função de questões internas e debilidades estruturais. A figura do Estado passa a ser central em função de dois fatores: por um lado a concentração da propriedade da terra que antes estavam baseadas em unidades esparsas e diversas e, por outro lado, o fraco desenvolvimento da manufatura e do comércio. Nesse aspecto, tem ascensão um novo arranjo societal de vida, com uma maior interação entre os indivíduos e, concomitantemente, maiores chances de desenvolvimento e expressão humanas (CHASIN, 2007).

A consolidação da democracia ateniense era dependente do desenvolvimento do império e este, por sua vez, dependia da expansão da cidadania, do proprietário de terra e, inclusive, para fora das fronteiras de Atenas. O século V, de modo geral, pode ser assim caracterizado pelas "lutas, disputas e problemas internos da pólis; o sucesso e o fracasso da hegemonia ateniense sobre a Ática, as outras cidades e a própria defesa do território grego" (CHASIN, 2007, p. 69).

Com o fracasso dos persas em 478 surge a liga Délica que permitiu o favorecimento dos interesses atenienses e gregos. O império de Atenas não surgiu em função de $m$ comércio exuberante, mas antes disso, em razão de questões de defesa, ou seja, "Atenas é levada a constituir o império ateniense não em função do desenvolvimento das forças produtivas, da expansão do comércio ou da manufatura [...]" mas sim, "uma unidade - para a defesa e preservação do território" (CHASIN, 2007, p. 70). Observamos uma sociedade cuja economia estava muito dependente da arrecadação de impostos. É por isso que a Liga ajudou o império no sentido de prover recursos para a reprodução da democracia ateniense. Isto mostra que "pela política, instituiu-se a não liberdade, a escravidão; no plano externo, o Estado impôs, a título de defesa territorial, um conjunto de obrigações que, diretamente subordinaram as cidades" fazendo com que os tributos fossem impostos e isto garantiu "a vida de Atenas e de seus cidadãos" (CHASIN, 2007, p. 71).

Importante notar que a queda da pólis não significou o fim do mundo antigo. Assistimos à expansão da cultura grega perante outros povos e a cultura helênica se torna muito disseminada perante a antiguidade. $O$ domínio macedônico acabou por transformar a democracia grega apenas algo formal, sem a mesma força que antes usufruíra. Quem de fato determinava dos rumos, agora, não eram mais os cidadãos gregos; mas os generais macedônicos, ou seja, interesses extrínsecos aos gregos. O século de Aristóteles será também aquele em que surgirão fortunas amealhadas pelo comércio e pela usura. O próprio Aristóteles irá condenar estas formas de enriquecimento em sua "Política", já que a usura, por exemplo, "não visa à autossubsistência e ao bem da comunidade" (CHASIN, 2007, p. 82). O que é condenável não é a riqueza, para o filósofo discípulo de Platão, mas a riqueza para fins pessoais apenas e não mais a comunidade e, por isso mesmo, para ele "só a justa medida - estabelecida pelo Estado e pela ética - poderia, talvez recolocar a comunidade política em seus anos de glória e unidade política do século V" (CHASIN, 2007, p. 83).

\section{ARISTÓTELES: UM CLÁSSICO PARA A PESQUISA E PRÁTICA EM EDUCAÇÃO}

Aristóteles nasceu em 384 a. C. na cidade de Estagira. Seu pai, Nicômaco, era médico de Aminto, rei da Macedônia e faleceu quando o filósofo contava apenas com a idade de sete anos. Sua instrução ficou a cargo do seu tio, Proxeno. Pouco se sabe desse período e, provavelmente, a infância de Aristóteles foi em 
Pela, capital da Macedônia. Quando completou dezoito anos, se mudou para Atenas, que à época oferecia a melhor formação intelectual disponível. Frequentou a Academia de Platão e lá permaneceu durante vinte anos até a morte deste. Com o falecimento de Platão a Academia fica na direção de Espeusipo e passará a ser orientada enfaticamente pela matemática e astronomia. Aristóteles não concordando com esta linha de pensamento que tenta identificar a filosofia à matemática e, ainda, em razão do clima antimacedônico que se instaura em Atenas em razão do saque de Olinto em 348 a. C.; resolve, junto com Xenócrates se mudar para Assos na Eólida. Esta cidade estava sob o governo do rei de Hérmias e Aristóteles contrai matrimônio com a filha desse rei, Pítia (CHAUÍ, 2002).

Hérmias tinha realizado a construção de uma escola platônica e Aristóteles passa a lecionar lá durante três anos. Com o assassinato de Hérmias, o filósofo se muda para Mitilene e em 342 a. C. Filipe da Macedônia o chama para Pela com a responsabilidade de cuidar da educação de Alexandre, seu filho, que contava com quatorze anos naqueles tempos. Acredita-se que Aristóteles tenha ensinado Alexandre que a Grécia não conseguiria se sustentar se continuasse com a existência de cidades rivais, todavia, o dilema era resolver esta questão sem ser necessário recorrer à criação de um governo centralizado. Além disso, outra ideia difundida era de que a Macedônia tinha mais influência grega do que oriental e que a união pacífica entre gregos e "bárbaros" seria inviável, pois os gregos estariam mais acostumados à liberdade e os "bárbaros" ao despotismo (CHAUÍ, 2002).

Ao que tudo indica, Alexandre não concordou com os ensinamentos de Aristóteles e, quando assumiu o poder ordenou a execução de Calístenes, um historiador amigo do filósofo. Aristóteles com receio de ser considerado culpado por alguma crítica ou posicionamento que pudesse ser-lhe atribuído, resolve se mudar para Atenas e funda o seu Liceu em 335 a. C. O Liceu dirigido por Aristóteles de 335 a 323 a. C. era formado por um edifício, jardins e um "perípatos", ou seja, uma área para passeio na qual o filósofo e seus alunos passavam e discutiam temas e reflexões filosóficas. Todos os dias, no período da manhã, Aristóteles dava aula de filosofia aos mais adiantados e durante as tardes e noites se dedicava em cursos e lições para públicos mais abertos. Teofrasto e Eudemo, seus discípulos, ajudavam na monitoria de tais cursos e anotavam os ensinamentos de seu mestre. Alexandre morre em 323 a. C. e o clima antimacedônico ressurge em Atenas. Some-se a isso, as ligações de Aristóteles com a Macedônia e a antipatia nutrida pela Academia e a escola de Isócrates para com o Liceu, o filósofo é acusado de impiedade e deixa Atenas para se mudar para Cálcis. Meses depois, em decorrência de uma enfermidade no estômago, Aristóteles morre em 321 a. C. com sessenta e três anos de idade (CHAUÍ, 2002).

Importante sinalizar que o conceito de clássico aqui neste texto está em coerência com a Pedagogia Histórico-Crítica (PHC) em seus dois significados. Trata-se da defesa do conhecimento clássico e elaborado das ciências, das artes e da filosofia na educação escolar, num primeiro sentido e, num segundo sentido, trata-se da função clássica da escola em possibilitar a apropriação e transmissão do patrimônio cultural sistematizado que fora amealhado pela humanidade ao longo da história, como Saviani (2011; 2021) permite compreender.

A obra de Aristóteles aqui em debate atende a estes dois significados de clássico e isso justifica a sua escolha e análise. A "Ética a Nicômaco" se conforma num texto formado por dez livros nos quais Aristóteles discute vários temas: o bem, a felicidade, a virtude e a justiça. Estamos convencidos de que o seu estudo pode contribuir com reflexões que permitam repensar a educação e seus desafios, ou melhor, problematizar a educação nas relações de sua própria orgânica e no dinamismo desempenhado com a síntese do todo. A defesa da apropriação dos clássicos da cultura humana; a importância do estudo com rigor; a racionalidade; o conhecimento científico objetivo e a verdade científica são exemplos de lições deste escrito aristotélico que ainda continuam essenciais para pensarmos o debate em educação. Começa o filósofo de Estagira afirmando que:

Admite-se geralmente que toda arte e toda investigação, assim como toda ação e toda escolha, têm em mira um bem qualquer; e por isso foi dito, com muito acerto, que o bem é aquilo a que todas as coisas tendem [...] Se, pois, para as coisas que fazemos existe um fim que desejamos por ele 
mesmo e tudo o mais é desejado no interesse desse fim; e se é verdade que nem toda coisa desejamos com vistas em outra (porque, então, o processo se repetiria ao infinito, e inútil e vão seria nosso desejar), evidentemente tal fim será o bem, ou antes, o sumo bem. (ARISTÓTELES, 1979, p. 49)

$\mathrm{O}$ que temos neste trecho? Em primeiro lugar, a assertiva de que as atividades humanas possuem uma finalidade, ou seja, de que os atos dos indivíduos possuem uma teleologia. Em segundo lugar, que cada dimensão ou práxis, existe uma função que se é desempenhada na sociedade. Aqui, podemos refletir na educação a necessidade da prática docente ser guiada por uma intencionalidade, com clareza sobre os fins e os objetivos a serem alcançados. Podemos elaborar uma crítica ao espontaneísmo e ao praticismo que, exasperado na imediaticidade fenomênica, subjuga a questão dos conteúdos e da meta a ser atingida em razão da superficialidade cotidiana. Saviani (2011) também entendendo a atividade educativa como uma atividade que deve possuir finalidades, já afirmou que: "o trabalho educativo é o ato de produzir, direta e intencionalmente, em cada indivíduo singular, a humanidade que é produzida histórica e coletivamente pelo conjunto dos homens" (SAVIANI, 2011, p. 13).

Isso se dá, inclusive, ao se abandonar categorias centrais para a razão e a reflexão filosófica e científica, como verdade e falsidade:

Ao tratar, pois, de tais assuntos, e partindo de tais premissas, devemos contentar-nos em indicar a verdade

aproximadamente e em linhas gerais; e ao falar de coisas que são verdadeiras apenas em sua maior parte e com base em premissas da mesma espécie, só poderemos tirar conclusões da mesma natureza. E é dentro do mesmo espírito que cada proposição deverá ser recebida, pois é próprio do homem culto buscar a precisão, em cada gênero de coisas, apenas na medida em que a admite a natureza do assunto. (ARISTÓTELES, 1979, p. 50)

A verdade não é construída pelo sujeito, segundo Aristóteles. Antes disso: ela é descoberta, tradução, explicitação, apreensão do movimento. Por isso, o filósofo discípulo de Platão usa a expressão "indicar a verdade aproximadamente e em linhas gerais"; já que o conhecimento é sempre cumulativo e superável. Pensemos, por exemplo, no que se conhecia a respeito das células, quantos modelos científicos não foram criados no intuito de expressarem a constituição delas e, quantos modelos não foram justamente superados por outros que se aproximavam cada vez mais da realidade tal como ela é. O mesmo pode ser dito dos átomos, dos elementos da natureza, da física, química etc. Trabalhar com conhecimentos científicos verdadeiros significa ter como parâmetro resolutivo a realidade, buscar entende-la como ela é em seu funcionamento e estruturação mais íntimos. Para a educação, tanto na pesquisa, quanto na atuação diretamente pedagógica, isto é fundamental: o pesquisador e o professor precisam trabalhar com o que de mais elevado existe de conhecimento científico verdadeiro na área ou disciplina em que atuam e não com base em opiniões ou "achismos" de qualquer tipo. Por isso mesmo que "em suma, a escola tem a ver com o problema da ciência. Com efeito, ciência é exatamente o saber metódico, sistematizado" (SAVIANI, 2011, p. 14). Em outras palavras:

Assim, o homem que foi instruído a respeito de um assunto é bom juiz nesse assunto, e o homem que recebeu instrução sobre todas as coisas é bom juiz em geral. Por isso, um jovem não é bom ouvinte de preleções sobre a ciência política. Com efeito, ele não tem experiência dos fatos da vida, e é em torno destes que giram as nossas discussões; além disso, como tende a seguir as suas paixões, tal estudo lhe será vão e improfícuo, pois o fim que se tem em vista não é o 
conhecimento, mas a ação. E não faz diferença que seja jovem em anos ou no caráter; o defeito não depende da idade, mas do modo de viver e de seguir um após outro cada objetivo que Ihe depara a paixão. A tais pessoas, como aos incontinentes, a ciência não traz proveito algum; mas aos que desejam e agem de acordo com um princípio racional o conhecimento desses assuntos fará grande vantagem. (ARISTÓTELES, 1979, p. 50)

Novamente temos a defesa clara a apropriação da ciência, do estudo e do rigor como requisitos indispensáveis para a análise, para o confronto de teorias, para o discernimento e a razão. Em Aristóteles temos uma articulação entre teoria e prática que considera o conhecimento teórico como relevante no entendimento da realidade objetiva e como prelúdio para a ação bem orientada. A teoria parte da realidade e a ela se volta no sentido de sua intervenção. Para isso, o uso da razão, fundamentada com base na experiência e no conhecimento científico que supere as aparências defendidas pelo senso comum é um conditio sine qua non. Podemos verificar isso, quando argumenta que "é pelos indivíduos de grande sabedoria prática que procuram ser honrados, e entre os que os conhecem e, ainda mais, em razão da sua virtude" (ARISTÓTELES, 1979, p 52). Não se trata de um conhecimento que se rende às aparências. Por outro lado, é um conhecimento que as supera, sem abandonar o real, sem lucubrações fantasiosas. Saviani (2011) também defende a ciência na educação escolar, pois a "opinião, o conhecimento que produz palpites, não justifica a existência da escola. (SAVIANI, 2011, p. 14).

A verdade e a razão, em Aristóteles, possuem íntima relação com a sua concepção de "bem universal":

Seria melhor, talvez, considerar o bem universal e discutir a fundo o que se entende por isso, embora tal investigação nos seja dificultada pela amizade que nos une àqueles que introduziram as Formas. No entanto, os mais ajuizados dirão que é preferível e que é mesmo nosso dever destruir o que mais de perto nos toca a fim de salvaguardar a verdade, especialmente por sermos filósofos ou amantes da sabedoria; porque, embora ambos nos sejam caros, a piedade exige que honremos a verdade acima de nossos amigos. (ARISTÓTELES, 1979 , p. 52)

Ou seja: a verdade não pode se curvar aos posicionamentos já consagrados, não pode temer confrontá-los, questioná-los. Aliás, é muito em função disto que a grande filosofia em diversos exemplos ao longo da história tem perturbado o sono da tranquilidade daqueles que exercem o poder. Aristóteles defendia a pólis e o "bem universal" é o bem da comunidade de cidadãos. O filósofo, em seu realismo adstringente para muitos, admite a existência da essência dos objetos e, inclusive da totalidade:

Ora, o termo "bem" é
usado tanto na categoria
de substância como na de
qualidade e na de relação,
e o que existe por si
mesmo, isto é, a
substância, é anterior por
natureza ao relativo (este,
de fato, é como uma
derivação e um acidente
do ser); de modo que não
pode haver uma Ideia
comum por cima de todos
esses bens. (ARISTÓTELES,
1979, p. 53)

Essa é outra grande lição que podemos refletir na educação: a relação entre essência e aparência. Para o filósofo em tela a essência teria um caráter "que existe por si mesmo"; todavia, é importante entender que ele compreendia a existência da essência e aparência. No ensino e na pesquisa esta distinção é fundamental rumo à produção da ciência e das teorias educacionais, caso contrário, reitera-se o que já se conhece e a compreensão da realidade não superará no nível da sua camada mais epidérmica. O objetivo da educação escolar, numa perspectiva humanogenérica, para a $\mathrm{PHC}$ é o crescimento intelectual 
dos alunos (SAVIANI, 2011) e, nesse aspecto, o conhecimento clássico das artes, das ciências e da grande reflexão filosófica são indispensáveis para um entendimento histórico e crítico do mundo e da sociedade.

Além disso, Aristóteles ao se indagar o que o bem é, nos faz refletir sobre a finalidade e as ações, já que "em todas as ações e propósitos é ele a finalidade; pois é tendo-o em vista que os homens realizam o resto" (ARISTÓTELES, 1979, p. 54). Aqui também reside uma grande contribuição para a reflexão educacional: qual formação esta sociedade está produzindo? Há possibilidades reais e concretas para o desenvolvimento intelectual, físico, artísticocultural, científico e filosófico para todos os indivíduos em seu processo formativo? Questões essenciais para 0 debate preocupado com 0 vínculo da dimensão educativa à síntese das interações que desenvolve junto às outras esferas da vida. Por isso mesmo a importância do rigor em expressar a objetividade efetiva daquilo que se investiga:

Mas a cada conjunto de
princípios devemos
investigar da maneira
natural e esforçar-nos
para expressá-los com
precisão, pois que eles
têm grande influência
sobre o que se segue. Diz-
se, com efeito, que o
começo é mais que
metade do todo, e muitas
das questões que
formulamos são aclaradas
por ele. (ARISTÓTELES,
1979, p. 57)

Há a necessidade de buscar a gênese e desenvolvimento daquilo que se pesquisa e, ainda, a sua articulação com o todo, com a totalidade, no sentido de "expressá-los com precisão" como nos diz Aristóteles, caso contrário, tanto o entendimento quanto a intervenção no real ficarão profundamente debilitados. Assim:

[...] pode existir o estado de ânimo sem produzir nenhum bom resultado, como no homem que dorme ou que permanece inativo; mas a atividade virtuosa, não: essa deve necessariamente agir, e agir bem. E, assim como nos Jogos Olímpicos não são os mais belos e os mais fortes que conquistam a coroa, mas os que competem (pois é dentre estes que hão de surgir os vencedores), também as coisas nobres e boas da vida só são alcançadas pelos que agem retamente. (ARISTÓTELES, 1979, p. 5758)

Temos a "atividade virtuosa" relacionada com aqueles que "agem retamente", ou seja, para Aristóteles, há uma articulação entre ciência, razão, virtude e ação. O âmbito do escopo teórico escapa e se distancia da mera contemplação especulativa descolada de preocupações práticas e, ao mesmo tempo, não se resume acriticamente à insuficiência do aparente. Por isso mesmo, para o filósofo em questão, são virtudes intelectuais "a sabedoria filosófica, a compreensão e a sabedoria prática" (ARISTÓTELES, 1979, p. 64).

Enfim, Aristóteles foi um filósofo que elaborou indispensáveis reflexões e ensinamentos à luz do campo de possibilidades de uma pólis em decadência. Acreditamos, contudo, que apesar de seus limites, as contribuições que sua obra e, em especial a "Ética a Nicômaco" pode oferecer à educação são enormes. Podemos apontar, sumariamente, seis grandes contribuições do estudo dessa obra aristotélica a partir da PHC: 1) a defesa da apropriação dos clássicos da ciência e da filosofia; 2) o estudo e o rigor como necessários para a atividade com a ciência; 3) a necessidade do conhecimento verdadeiro; 4) a distinção entre essência e aparente; 5) a consideração da existência do todo, da totalidade e 6) a articulação entre virtude, ciência e prática. Estas contribuições e muitas outras comprovam o fato de que Aristóteles é um clássico que precisa ser redescoberto pelo debate educacional, pois como afirma Duarte (2015): "O critério da pedagogia histórico-crítica para a seleção e organização dos conteúdos escolares é, pois, o do desenvolvimento de cada pessoa como um indivíduo que possa concretizar em sua vida a humanização alcançada até o presente pelo gênero humano" (DUARTE, 2015, p. 09) 


\section{CONSIDERAÇÕES FINAIS}

A filosofia não deve se conformar num conjunto de conhecimentos enciclopédicos para especulação e erudição da razão que se volta a si mesma num castelo enclausurado de emanações acima do mundo terreno. Ao contrário, entendemos, que o conhecimento científico e a filosofia clássica se voltam para a análise do real, de suas articulações entre essência e aparência em sua dinâmica movente e movida ao longo da história. Concordamos com o posicionamento de que:

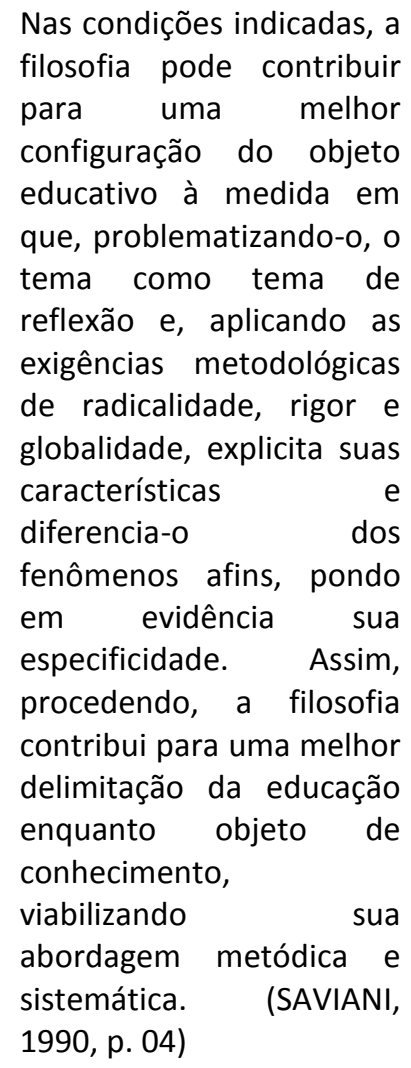

É nesse sentido que Aristóteles, enquanto clássico da cultura grega entre o apogeu e a decadência, apresenta importantes contribuições para o debate em educação no que se refere à pesquisa e à prática pedagógica docente. Não se trata de endeusá-lo sem maiores questionamentos. As suas limitações e tentativas de retorno à um patamar societário já em crise demonstram a vinculação das expressões ideais em face do campo de possibilidades efetivado pela objetividade.

É preciso redescobrir a vivacidade de seu pensamento enquanto prelúdio necessário para o reequacionamento e a compreensão racional da educação em face à totalidade social na qual se relaciona e dinamiza. A defesa do rigor, da ciência, do conhecimento verdadeiro, da relação teoria e prática que não supervaloriza uma em detrimento da outra, mas que encontra uma reciprocidade dialética entre ambas e a valorização dos clássicos são elaborações e lições valiosas para educadores e pesquisadores comprometidos com o entendimento crítico da dimensão educativa, pois "é mister que o educador se eleve do senso comum ao nível da consciência filosófica de sua própria prática" (SAVIANI, 1990, p. 09).

Partir das causas, analisar seus fins, seus objetivos e refletir sobre suas articulações são exemplos de problematizações que "Ética a Nicômaco" pode oferecer e, de modo geral, o conjunto da obra aristotélica, no compromisso com a verdade, já que Aristóteles possuía um "vasto, profundo, universal e multilateral esforço para apanhar filosoficamente a realidade em seu conjunto" (LUKÁCS, 2013, p. 68).

\section{REFERÊNCIAS}

ANDERSON, P. Passagens da Antiguidade ao Feudalismo. São Paulo: Brasiliense, 1991.

ANGIONI, L. O ser humano cultivado (pepaideumenus) em Aristóteles. Filosofia e Educação, v. 9, n. 01, p. 165-196, 2017. https://doi.org/10.20396/rfe.v9i1.8648432

ARISTÓTELES. Ética a Nicômaco. Tradução de Leonel Vallandro e Gerd Bornheim da versão inglesa de W. D. Ross - "Os Pensadores - II". São Paulo: Abril Cultural, 1979.

CHASIN, M. Política, Limite e Mediania em Aristóteles. 2007. Tese (Doutorado em História) Universidade de São Paulo - USP, São Paulo,2007.

CHAUI, M. Introdução à história da filosofia: dos pré-socráticos a Aristóteles. 2. ed. São Paulo: Companhia das Letras, 2002. v.1.

DUARTE, N. A Importância da Concepção de Mundo para a Educação Escolar: Porque A Pedagogia Histórico-Crítica não endossa o silêncio de Wittgenstein. Revista Germinal, v. 7, n. 1, p. 825 , 2015. https://doi.org/10.9771/gmed.v7i1.12808

LUKÁCS, G. Para uma Ontologia do Ser Social - II. São Paulo: Boitempo, 2013. 
SAVIANI, D. Contribuições da Filosofia para a Educação. Revista Em Aberto, ano 09, n. 45, p. 29, 1990.

SAVIANI, D. Pedagogia Histórico-Crítica: Primeiras Aproximações. Campinas,SP: Autores Associados, 2011.

SAVIANI, D.; DUARTE, N. (orgs.). Pedagogia histórico-crítica e luta de classes na educação escolar. Campinas,SP: Autores Associados, 2012. https://doi.org/10.9771/gmed.v5i2.9697

SAVIANI, D. Educação Escolar, Conhecimento e Pesquisa. Revista GESTO-Debate, v. 21, n. 08, p. 134-152, jan./dez., 2021. 